\title{
From Past Aspirations to Present Achievements: A Case Study of Three K-8 Schools Successfully Educating Roma Students
}

\author{
Svjetlana Curcic \\ University of Mississippi \\ U. S. A. \\ Goran Lapat \\ University of Zagreb \\ Croatia \\ Branko Susec \\ Department for Education, Culture and Sport \\ Medjimurje County \\ Croatia \\ Benjamin Ignac \\ European Roma Rights Center \\ Hungary
}

ABSTRACT: This case study focuses on education in three K-8 schools in

Medjimurje County, Croatia. The object of inquiry is the development of successful educational practices for Roma students. Until recently, only a limited number of Roma students completed basic K-4 schooling. Today all students at these three schools complete K-8 education, with some Roma students going on to pursue secondary and tertiary education. We examine some of the processes that took place in creating the change, along with the principals', teachers', and Roma assistants' views and actions.

KEYWORDS: Roma students, elementary education, middle school, Croatia, case study

\author{
Method \\ Data Collection and Analysis \\ Findings \\ Conclusion \\ References \\ Author Contact
}

\begin{abstract}
A number of studies and policies related to education of Roma students have several assumptions in common: Roma youth are undereducated; the lack of education has negative consequences for their labor prospects and, in turn, perpetuates the cycle of Roma marginalization (Brüggemann, 2012; Rostas \&
\end{abstract}


Kostka, 2014; World Bank, 2010). Accompanied by prejudice and discrimination, the educational, social, and political marginalization of the Roma population has persisted for centuries across a number of European countries. This centuries-old social exclusion and ghettoization has been described and reported in various forms (e.g., Fonseca, 1995; Miskovic, 2013), including theme issues of Alberta Journal of Educational Research in 2015 (Volume 61, Issue 4) and European Educational Research Journal in 2014 (Volume 13, Issue 3).

In this study, we focus on three K-8 schools in Croatia that transformed the way they educate their Roma students. The primary purpose of this case study is to share lessons learned from these dedicated educators. Two questions guided the study:

1. What kinds of processes are involved in developing successful educational practices in educating Roma youth?

2. From the perspective of educators, which practices have shown promising results?

\section{The Context}

The three K-8 schools that constitute our case study are situated in Medjimurje County at the northern part of Croatia, bordering on Slovenia and Hungary, close to Austria. The first written record of the Roma population presence in Croatia dates back to the year 1362, but Roma's first recognition as one of 22 national minorities was noted in the Amendments to the Constitution of Croatia only in 2010 (Croatian Parliament, 2010). In our study, as in many documents including the Croatian Constitution, the term Roma is used as an umbrella term inclusive of heterogeneous Roma groups (including some of the Roma groups living in Croatia such as the Kalderash, the Lovar, the Ashkali, and the Bayash groups).

The Bayash Roma who live in Medjimurje County speak an old dialect version of the Romanian language as their first language. Beginning elementary education in the Croatian language presents the first barrier to the successful education of Roma children. To address this language barrier, some schools created classrooms with Roma-only students, a practice eventually presented as a case of discrimination and segregation at the European Court of Human Rights (ECHR) in Strasbourg: Oršuš and Others vs. the Republic of Croatia (ECHR, 2010). While the ECHR court had some understanding for the initial separate placements in the elementary grades, it disapproved of the continued Roma students' segregation in later grades. One of the schools involved in the ECHR court case is also one of the schools involved in our study.

To provide further context for the study, we present several reports relevant to Roma education in Croatia since the 2000s. In that time period, specifically between 2004 and 2007, the European Union (EU) experienced an enlargement as Bulgaria, The Czech Republic, Estonia, Hungary, Latvia, Lithuania, Poland, 
Romania, The Slovak Republic, and Slovenia joined the EU. At this point, Croatia was still an accession state aspiring to join the EU. Thirty-five fields form the basis of the accession negotiations for each candidate country. Candidate countries are expected to adapt their administrative and institutional infrastructures and bring their national legislation into line with EU legislation (European Commission, 2016). Among these 35 fields, negotiated as chapters, the protection of minorities was one of the key elements to accession (Sobotka \& Vermeersch, 2012), yet it became clear that there was little political will and limited means to hold the countries accountable for minority rights and protection once they joined the EU. Within this context, the EU promoted the Decade of Roma Inclusion (2005 -2015). As an accession state, Croatia was one of 12 states that participated in the Decade of Roma Inclusion. In 2005, the states developed Action Plans to address Roma inclusion in the fields of education, health, housing, and employment, but most states, including Croatia, did not have clearly established baselines and indicators of progress (Curcic, Miskovic, Plaut, \& Ceobanu, 2014).

In 2010, Croatia engaged the National Centre for External Evaluation of Education (NCEEE) to gather and analyze data related to the education of Roma children. The Ministry of Science and Education recommended a sample of 26 schools in eight counties that educate Roma students along with other students. In determining the sample in terms of grade levels, it became obvious that a large number of Roma students drop out in later grades. Recognizing the interrupted schooling of Roma students in later grades, the sample was limited to $4^{\text {th }}$ and $6^{\text {th }}$ graders rather than $4^{\text {th }}$ and $8^{\text {th }}$ graders as originally planned (NCEEE, 2010). Twenty-six schools were surveyed electronically and 24 completed the survey. These 24 schools returned the survey with responses from students, parents, and teachers. According to the survey results, there were 1,247 students in $4^{\text {th }}$ grade in total, with 346 Roma students. Eighty-two percent of the students repeating one grade were Roma students. Ninety-one students followed education programs with accommodation plans, and $70 \%$ of those were Roma students. Special education with individualized programs was in place for 12 students, three of whom were Roma. Similar numbers were reported for $6^{\text {th }}$ graders, with an increased number of special education individualized programs for Roma $6^{\text {th }}$ graders, possibly indicating a tendency toward Roma students' overrepresentation in special education (White, 2012).

The NCEEE (2010) report indicated, on a Likert scale of 1 through 5, that the students seemed to like going to school $(M=3.75, S D=1.61)$. The responses from Roma students were not significantly different from those of their peers. Although Roma and non-Roma students also similarly evaluated the importance of particular subjects (Croatian language, math, science and social studies and foreign language), Roma students reported significantly lower average grades in those subjects (NCEEE, 2010). Roma parents considered the education of their child to be very important $(M=4.90, S D=.40)$, as did other parents $(M=4.97, S D=$ .27). Finally, teachers viewed multicultural classrooms predominantly as an opportunity for children to learn tolerance $(69 \%$ of $241 \mathrm{~K} 5-12$ teachers and $78.6 \%$ of 176 elementary teachers). Understanding other cultures was the second most common response (NCEEE, 2100). 
In a study of early childhood education in Croatia, Šikić-Mićanović, Ivatts, Vojak, and Geiger-Zeman (2015) reported on multiple barriers, starting in elementary education, that contribute to poor levels of progress of Roma students:

limited participation and poor levels of progress; poor pupil motivation... mirrored by low teacher expectations; lack of teacher encouragement and ...challenging curricula; grade failure and repeats at crucial age stages; a real lack of teachers' intercultural competence...; unaddressed racist bullying of Roma pupils; ethnic segregation by class or pupil grouping within classes; ... premature drop-out from the education system. (p.16)

Following the Oršuš and others vs. the Republic of Croatia court case, the preschool funds for Roma children sharply increased in 2012 and 2013 (ŠikićMićanović et al., 2015). Still, as Šikić-Micanovic et al. (2015) reported, only $20 \%$ of Roma communities in Croatia have access to any kind of early childhood services. The lack of early childhood services for Roma children persists in a number of the EU member states (Urban, 2015).

As an accession state, Croatia could use, and indeed did use, the Instrument for Pre-Accession Assistance funds (IPA). The IPA funds offer preaccession assistance to help the candidate countries for EU membership meet the accession criteria in the following fields: transition assistance and institution building, cross-border cooperation, regional development, human resources development, and rural development (European Commission, 2016). Croatia joined the European Union as its $28^{\text {th }}$ member in 2013. The Decade of Roma Inclusion (2005-2015) policy was replaced by the European Union's National Roma Integration Strategies 2013-2020, allocating at least 20\% of funds in each member state to combat poverty and social exclusion of its Roma population.

Referencing the international assistance through IPA funds is important in our case study because those funds contributed to much needed legalization of seven out of eight Roma settlements in Medjimurje County. Most Roma settlements were rebuilt at their existing locations, with a number of houses built anew in accordance with a local ordinance. Without legal settlements, residents cannot have legal access to water or electricity. Such home conditions contributed (and in some cases still do so) to poor schooling outcomes. Within the context of our case study, learning about home conditions of their Roma students was transformative for the teachers.

\section{Method}

The case study method employed in our study might simply be defined as an exploration of a phenomenon of Roma education studied in a bounded context (Miles \& Huberman, 1994). Yet, some researchers advocate for more specificity because seminal works on case-study methods (e.g., Merriam, 1988; Stake, 1995; Yin, 2003) differ to some extent in their theoretical orientations (Baxter \& Jack, 2008; Yazan, 2015). Our case study framework aligns with Stake's (1995) 
proposition that the focus on the case might involve multiple methods. In that sense, a case study is not solely a method, but also a design framework for studying a phenomenon in a real-life context (Thomas, 2011).

Thomas (2011) proposes a useful typology in presenting a case study method. First of all, he distinguishes between the subject (the case itself) and the object (the analytical framework). The subject in our study, or the case, comprises three K-8 schools with a relatively large number of Roma children. The object of the study, or the analytical framework, is successful education of Roma children. It will become clear later in the text that the attribute "successful" comes from the researchers' perspective, while those involved were rather modest in the evaluation of their own educational practices. We do not present here the difference in perspectives as contradiction, but rather as multiple perspectives inherent in case studies (Stake, 1995).

Case studies are traditionally bounded by time and place, and we define the microcosm of our case as that of Medjimurje County, one of 21 counties in Croatia. The choice of the schools to be studied was determined by their "outlier" status as "successful" schools (Thomas, 2011, p. 514). The outlier or atypical status was based on local knowledge about education of Roma students and was supported by two of the authors of this study, who also are members of the Medjimurje County community.

Our research is bounded in time (2016-2017) in terms of observations and interviews. Although our focus was on change in educational practices, we do not characterize our study as evaluative (Merriam, 1988). Rather, it is an instrumental case study aiming to promote an understanding about successful educational practices (Stake, 1995).

\section{Purposeful Sampling}

The schools chosen for this study were purposefully selected because of their past and present education of Roma children in kindergarten through $8 \mathrm{~h}$ grade.

K-8 School 1 currently educates 429 children in total, with 328 Roma children $(77 \%)$. This K-8 school was formed by joining two schools into one in 1999. Until then, the two schools had had a student population that included $40 \%$ Roma children. The principal had worked as a teacher for a decade before she became the principal in this K-8 school in 1999.

K-8 School 2 educates 275 students in total, with 67\% Roma students. In the past, students from this school were educated in two schools, a K-4 and a Grade 5-8 school, with a larger number of students (364 students), but a smaller number of Roma students (22.5\%). The principal had worked as an elementary teacher for five years before he became the principal in 2004. 
K-8 School 3 educates 440 students in total, with $79 \%$ Roma students. In the past, there were approximately $50 \%$ Croatian children and $50 \%$ Roma children attending this school. The principal had been a teacher for eight years before she became the principal of the school in 2000.

All three schools had experienced an increase in the number of Roma students over the last decade. Although the population of Croatia has been consistently declining because of a combination of low fertility rates and emigration (United Nations, 2017), an increase in the Roma student population in Medjimurje County is predominantly related to an increased number of Roma children attending and completing obligatory education for children ages seven through 15 (Šikić-Mićanović et al., 2015).

\section{Data Collection and Analysis}

Learning about the towns, the adjacent Roma settlements, and the schools was a two-step process. In 2016, we had several meetings with the county administration, the Department of Education faculty, and several Roma residents in the area. By the time these activities were completed, the school year was over. We returned the next year with schools still in progress, with an aim of (a) observing instruction and (b) conducting further interviews. Two of the authors of this study were instrumental in this process, as they already had long-standing relationships with the community.

After obtaining permissions to conduct observations and interviews from the three schools involved, we conducted open-ended interviews with three principals, 10 teachers, two pedagogy specialists, two social workers, and two Roma teaching assistants. We also informally talked with several Roma residents. In addition, we conducted observations in three focal schools in three classrooms, each at different grade levels and subject areas, including in newly established afterschool programs.

We assured our participants that the results of the study were to be reported in anonymous terms: for example, no real names of the schools, educators, or students were to be reported. We asked the principals, teachers, social workers, pedagogues, and Roma assistants to consider the following questions:

1. When and how did the first efforts to change educational practices in educating Roma students begin?

2. What are some of the factors that seem influential in improving outcomes of the Roma students?

These two main questions closely followed the research questions that guided our study. We did not have a long list of questions. Rather, the participants responded to our open-ended questions, and we asked some clarifying questions as needed. The participants' responses assumed a narrative turn. With one assistant, we took notes during and after the interviews and compared the notes 
immediately after the interviews and observations were completed. We analyzed the responses for emerging themes (Strauss \& Corbin, 1998; Stake, 1995). Data analysis revealed that there were a lot of commonalities, or "correspondences," in the responses across the participants (Stake, 1995, p.78). Triangulation of data and member checking were conducted through discussing the themes with two teachers, one pedagogy specialist, and two authors of this study.

\section{Findings}

Our observations started with exploring the microcosm of our case study. Supported by international funds, the county, and the state government of Croatia, many Roma residents had newly built houses, provided with electricity and water, and most with small gardens. We learned from several Roma residents that, until not long ago, they had used generators, which had to be frequently filled at some central location in their communities, to have any electricity. Today all houses in the three Roma communities we visited have electricity and water. We also observed and learned that the process of building houses intentionally followed an inclusive path: the additional housing for Roma residents was built toward and closer to nearby towns rather than away from them. In other words, the Roma settlements were extended to join the nearby towns in an attempt to remove social exclusion by starting with geographical considerations.

We informally interviewed one female and one male Roma individual who had graduated from the very schools we were visiting (and secondary and tertiary education as well). They reflected on Roma traditions: not all Roma parents have been supportive of education beyond elementary schooling, especially of their daughters, for instance, but they also reported that the Roma parents' attitudes have been changing. They observed that school practices have also been changing as the schools have been developing a more inclusive school climate. hey concluded that the young, educated Roma students share the same problems as other young people in the state, related to the overall low employment rates.

In the next two sections, we report on the themes that emerged as important in improving Roma students' outcomes according to the principals' views and actions and the teachers' and assistants' views and actions.

\section{Principals' Concerted Efforts}

All three principals stated that the changes in educational practices have been gradually developing over the last decade. One principal shared that more than a decade ago her school had tried to address poor living conditions by providing a shower for Roma children upon arrival at the school and asking parents to send clean clothes. However, parents did not send clean clothes (many of them had no water access) and the practice was eventually abandoned. In addition, 
Roma children had been required to enter the school through a different entrance (related to planned showering). The principal and the teachers realized that their good intentions might be counter-productive and only contributing to "the wall of otherness surrounding the Roma children." In summarizing the processes leading to change, this principal stated: "We have learned through trial and error." Yet, this modest statement does not give credit to her and the teachers' systematic and consistent work on improving their teaching practices, described later in the text.

The three principals made a concerted effort to participate in various projects financially supported by the Roma Education Fund, the EU, the United Nations International Children's Emergency Fund (UNICEF), and the county. One of the remarkable achievements was building a separate building to serve as the Roma Family Center and as a place for afterschool programs. According to one school's survey, $76.6 \%$ of the Roma parents believed that an afterschool program was a necessity in helping their children learn or complete their homework. In addition to afterschool programs, the principals and the teachers developed peersupported learning programs, support for learning Croatian as a second language, summer camps, and skills for taking care of the school's garden and orchard.

As one of the principals noted, the K-8 schools in our case study were three of only four schools in Croatia that had applied for the EU funds, out of 26 schools that educate Roma children. In addition to obtaining funds from international agencies, the principals were crucial in collaborating with the county administration to secure free preschool, seen as very important in developing Croatian language skills before starting elementary schooling. Medjimurje County, in collaboration with the Ministry of Science and Education, started to financially support free preschool in 2011, and since then, the preschools have been continually supported, each year for 10 months (September 1 through June 30).

The principals also collaborated with the county to secure free bus transportation to and from the schools. As Roma settlements are several miles away from the schools, walking to and from the schools presented a challenge during snowy winter months. Only one or two Roma students would appear in the schools when it snowed. In collaboration with the county, the principals and the teachers developed workshops for parents, described in the next section, along with forums on multicultural education and living aimed at the larger community.

\section{Collaboration with Roma Parents}

All three principals and 10 teachers interviewed viewed their efforts to get acquainted first hand with nearby Roma settlements as crucial in starting to change their educational practices. After visiting the Roma settlements, it became clear to the teachers that reading assigned literature or completing homework might not be possible for many children (e.g., crowded home-living situation or no electricity). The statistics for the Roma population in the county show that in 2006, when the first efforts to change educational practices began, $85 \%$ of adults had not 
completed K-8 school, 12\% had completed K-8 school, and 3\% had completed secondary/vocational education. In view of such statistics, it became clear that parents would not be able to help with homework.

In 2012-2013, the three schools introduced "Supportive Parenting" workshops. The schools partnered with the Open Academy Step by Step and, with the support of the International Step by Step Association (ISSA), created materials for parents whose children were to become first graders in the fall of the next academic year. The teachers met with parents once a week, 90 minutes a month, before the start of the school year. Seventy to $75 \%$ of the parents have participated in workshops for several months each year for the last four years. Just like their children, the future students, the parents first of all learned some rules: (a) We listen to each other; (b) We come on time; (c) We respect other persons' opinions; (d) We actively participate; and (e) We are all equal. The parents were taught premath skills (e.g., ways to measure things) and pre-literacy skills. For example, the parents were encouraged to interpret pictures (such as those of a mouse mother with little mice contemplating how to outsmart a cat) and tell a story. The parents' interpretations were added to the pictures. The parents were instructed to cut out the squares with pictures, mix them, and ask their children at home to sequence the story. The children also sometimes joined the workshops with parents. In addition, parents learned some sewing, cooking, and gardening skills. According to one of the principals, parents expressed that they always learned something new and useful and liked learning alongside their children. The parents also learned they were important in the educational process of their children regardless of their own level of education.

At the beginning, during workshops, Roma and non-Roma parents avoided sitting close to each other but eventually established a relationship through discussing their children. These informal sessions were crucial in developing a sense of community among Roma and non-Roma parents. In their interviews, five teachers, two social workers, and two pedagogy specialists reported an increase in the number of parents, especially Roma parents, who attended the school meetings. They also shared that a number of Roma parents started to stop by for individual consultations to discuss problems not only related directly to their children, but also to their own health issues, marital issues, and various other home-related issues. The educators learned that their working hours needed to be flexible to meet the needs of "their" parents. Unanimously, the principals and the teachers perceived the establishment of close collaboration with parents as the major turning point in the process of educating their Roma students. Outreach and cooperation with families resulting in positive outcomes in education of Roma children were similarly reported by Messing (2008) in the context of Hungary.

\section{Changing Instructional Practices}

Several teachers shared past experiences during which there were a lot of tears: "I cried every single day when I would come home from the school. I got a 
classroom full of Roma kids, and I did not know how to work with them. I talked with them about movies, hoping to establish some sort of relationship" (5th grade history/sociology teacher about the beginning of her teaching career a decade ago).

Several teachers shared their efforts to be "nice," hoping that children would be "nice." In return, though, one elementary teacher recalled that in spite of much effort she was referred to as a "cow." However, one of the middle school teachers shared how she gradually began to understand how to be "nice" while also establishing an authority, albeit not as an authoritarian figure: "I worked, first of all, on myself, and my own biases and predispositions; then, on figuring out how to establish boundaries....and some authority." One of the important themes that emerged across various educators' reflections on their changing practices was that they had first of all engaged in self-examination and questioning. One pedagogue summed it up: "I started to examine [six years ago] first of all my own assumptions, from personal to those that I learned at the university." She concluded, "There was yet a lot to learn".

One of the elementary teachers, currently teaching second graders, described the processes involved in changing her instructional practice. Her first step was to focus on creating a community of learners. Students in her classroom start a day sitting in a circle as opposed to looking at each other's back. During a morning meeting, the teacher and her students exchange news and at the end engage in a short relaxation game (5 - 15 minutes). The teacher stated: "This routine is very important for building our community." After their morning routine, the students work either individually or in small groups. The teacher teaches how to collaborate in small groups, how to respect each other's opinion, how to solve conflicts calmly through conversations and discussions, and how to articulate and defend one's position. "Because of such activities," she commented, "children are never silent and quiet as they constantly share their opinions."

Our classroom observations confirmed that the students indeed were seldom very quiet, but they clearly learned, followed all the routines, and were actively engaged in all the learning activities. In describing educational changes in small Hungarian communities with Roma children, Messing (2008) suggested that teaching students to collaborate in small groups is a good method, as children of various ethnic backgrounds are forced to cooperate, work together, and get to know each other.

The second grade teacher constantly presented challenges to her students, not only in the form of the curriculum to be mastered but also through such questions and directions as "Where could you search for information? In what sources?" In other words, as she stated, "I do not provide ready answers, but have them act as researchers who develop their own paths to learning." To gather her students' attention, the teacher raises her arm, a sign that they would switch to another activity. This way of gathering attention turned into another important routine: "I never raise my voice; it really would not be helpful." The teacher stated that developing routines requires time: "Yes, it takes time. Sometimes I wonder - 
do I really need this in my life? But," she acknowledged, "eventually, you find a message from a student, or you get a hug ... and, that's priceless!"

The second grade teacher noted: "Every child is different and you have to adjust your teaching methods to include pictures, hands-on materials, and so on." She also is a unique teacher who at the end of the school year writes a personal letter to each of her students. Here is an example:

Dear student X.,

I am proud to have been your teacher. Thank you for all the moments we shared. Be diligent. Be persistent and learn thoroughly. Respect everything that surrounds you. This is a way to your success. And remember, one does not need to shout to be heard.

Your teacher, X. (Source: Open Academy Step by Step, 2015)

The attention to the individual characteristics of the students was also evident in a math class in another focal school. When students were working on math problems, there was not one explicit way to approach a problem. Some students devised their own ways to remember carrying some numbers forward, and the teacher would not correct them as long as their unique operations eventually led to correct results. Every concept or formula was accompanied by a simple word problem related to students' everyday lives (e.g., division of candies). Kárpáti, Molnár, and Munkácsy (2014) stressed that conceptual gaps are some of the important reasons for the underachievement of Roma students and recommend embedding the concepts to be taught in real life situations.

The teachers have developed several integrated units in which some themes are explored over several years, over grades, and across various subject matters (e.g., World Water Day, International Roma Day, and Citizenship), with students involved in project-based learning. All the teachers and pedagogues in our case study viewed students as unique individuals. Indeed, not one educator referred to the students as Roma students (or non-Roma students). Teachers occasionally organized visits for K-12 students across different schools and engage (Roma and non-Roma) students in joint activities, intentionally aiming at developing intercultural understanding and relationships, as opposed to teaching "tolerance." We observed one such visit, and all children seemed to be enjoying themselves while talking, drawing, snacking, and at the end exchanging the drawings among themselves.

The teachers regularly met once a month to discuss their own teaching. Several pedagogues attended classrooms and observed the extent to which Roma children were included in learning activities as opposed to being simply included with other children through (non-segregated) placements. While not required, some teachers recorded their own instruction and reviewed the sessions with their colleagues. The collaboration with the Step by Step association seemed to have contributed to improved education through providing workshops focused on student-centered teaching. While the collaboration with Step by Step started by chance (e.g., some schools got an unsolicited email a decade ago), the teachers 
had embraced this venue for professional development. Most teachers mentioned their collaboration with this association as productive, not only in improving their teaching practices but also in developing workshops with parents, as mentioned earlier. Most teachers had been volunteering to work with parents in workshops for the last four years.

A common characteristic of the teachers interviewed is that they were constantly seeking ways to improve their practices. For example, they regularly attended and participated in international conferences, the latest being organized by Erasmus Plus held in Budapest in 2017 on the topic of reducing dropout rates. Nine educators, three from each of the three schools that constituted our case study, participated within the project titled PEARL: Preventing Early School Leaving through Inclusive Strategies, and shared their experiences on collaborating with Roma parents. In the fall of 2017, most teachers had started to attend an 8-week course in the Bayash dialect, organized with the support of the Step by Step association and the Roma Education Fund. The Bayash dialect is an archaic Romanian dialect that includes borrowings from other languages and as such has not been recognized as a "minority" language in Croatia (unlike Italian, for example). Therefore, the immediate goal for teachers was not necessarily to learn how to instruct students in the Bayash dialect, but rather to establish a welcoming climate, especially at the beginning of the school year, for both students and parents. Several teachers reported that they had already engaged in selfinstructed learning and mastered some basic phrases in the dialect. Indeed, we observed messages, rules, and writings across various classrooms in both the Croatian language and the Bayash dialect.

\section{Engaging Roma Assistants as a Bridge}

We interviewed two Roma assistants who contributed to instructional activities in the classrooms. Most teachers held very positive views about the Roma assistants, especially in establishing collaboration with those parents who have first graders in the schools. Yet, the Roma assistants themselves were not completely satisfied with their status within the school system. As one Roma assistant explained: "At the state level, the description of a 'Roma assistant' simply does not exist. Therefore, when a Roma individual applies for 'assistant in education' job, they are not to be viewed as preferred candidates, even in the schools with Roma children in majority." Nevertheless, several teachers considered having Roma assistants as very beneficial because "they bridge the communication/language/culture gap between the school and parents, in addition to working with students in the classrooms." The Roma assistants shared that they rode on the buses that transported the students to and from the schools and, when necessary, served as "messengers," dispersing some important information not only from the schools, but also from Roma settlements to the schools. In this way, the school-parent collaboration extended beyond the classrooms. The assistants in education had to have at least secondary education and additional training. 
Interestingly, one of the Roma assistants established a non-governmental organization UZOR: Udruga za Obrazovanje Roma/Association for Roma Education. While their first projects were presentations of traditional Roma vocations, music, and dance, they recently focused on improving Roma children's educational outcomes. For example, they collaborated with a local school on improving the educational outcomes for Roma children. Their work extended beyond K-8 to support Roma citizens on welfare in developing skills and vocational training to help them join the work force. Within a "Gastrostart project," for instance, they supported 20 Roma participants to develop knowledge and skills to become culinary chef assistants; 18 completed the training.

In all three schools, students' artwork was proudly displayed across the halls and on the doors; in some cases the doors were painted directly by the students. The children's artwork displayed everywhere created an impression that the schools indeed belonged to those children who attended them. Bright colors also contributed to the positive school climate felt throughout the schools.

\section{Expanding Educational Opportunities for Roma Children}

At the county level, there were 1,581 Roma children who started their elementary education in 2015-2016 (with 14 children unaccounted for), and in the same time period, there were 251 Roma students in secondary education (144 males and 107 females). The number of tertiary Roma students has been slowly increasing over the 2006-2016 period but has remained small compared to the rest of the population. Those teachers with 10 to 15 years of teaching experience reported that, until a decade ago, Roma children usually stopped their schooling soon after the $4^{\text {th }}$ grade; girls used to marry very young (12-14 years of age), and not many parents would encourage education beyond elementary school. In contrast, today all students in the three schools complete their K-8 education, with some going on to secondary and tertiary education.

Padilla-Carmona and Soria-Vílchez (2015) described good practices for widening participation of Roma students in higher education. One such practice is a scholarship program in the Roma Education Fund offered to Roma students in Albania, Bosnia and Herzegovina, Bulgaria, Croatia, Czech Republic, Hungary, Kosovo, Macedonia, Montenegro, Moldavia, Romania, Russia, Serbia, Slovakia, Turkey, and Ukraine. Further examples are Romaversitas, a training and scholarship program that supports Roma students in higher education established in Hungary in 1997, and the Roma Access Program established by Central European University focused on promoting the international mobility of Roma graduate students. However, the authors also note the lack of specific focus on higher education as opposed to "post-compulsory education," which implies the risk of promoting vocational training and thus limiting Roma students to low-skill occupations (Padilla-Carmona \& Soria-Vílchez, 2015, p. 23). 
By 2015-2016, all six-year-old Roma children in the region were included in preschool at no cost to Roma parents, and that practice, according to the teachers and principals, might be the best start for improving the outcomes of Roma students at all levels. Some changes were also introduced at the university level. The University of Zagreb has introduced some elective courses in Roma language and culture. The University of Zagreb has three Departments of Teacher Education, and one of them is situated in Medjimurje County, in the town of Cakovec. Because of an increasing number of Roma children attending elementary and middle schools in the region, the Teacher Education Department in Cakovec further revised the curriculum to better prepare their teacher candidates. The revisions have resulted in more focus on bilingual education, teachers' self-evaluations, and courses addressing multicultural education, with special attention to the Roma population and Bayash dialect in the region. Also, the faculty members have started to introduce their teacher candidates to Roma communities. Although some of the Roma settlements are only six miles away from the university location, for many of the future teachers this is the first time they will visit the communities from which their future students will travel to the local schools. In 2013, several current and former teacher education students established the Sfera (Sphere) association, with an aim to improve Roma first graders' language skills in afterschool programs. From several members, the Sfera association has grown to include 16 active members and volunteers, including some Roma members of the community. The number of students participating in the program has grown each year to include not only first graders, but also students across K-6 grade levels. Today, there are 130 students who participate in the afterschool program activities. Afterschool programs have been described as a "good practice" (Messing, 2008, p. 7). The "Learnery" afterschool programs in Hungary have been extended to 30 different locations and are the places where predominantly Roma, but also non-Roma students, engage in extra-curriculum activities (Messing, 2008). Afterschool programs are especially important for those children who might not have access to all the necessary school materials, including computers, in their homes.

\section{Conclusion}

The change in instructional practices in educating Roma students started with the teachers, who first of all engaged in examining their own cultural heritage and biases. In the process of reaching out to Roma students, their parents, and their settlements, and looking inward through self-examination, the teachers created communities in and outside the classrooms. Without those journeys, the international assistance might not have had much impact, as noted by Ram (2015). As an example of the limited achievement of international organizations based on national and local resistance to change, Ram cited the example of the Czech Republic that continues to place Roma children in segregated schools and the Czech president Zeman, who believes that "multiculturalism...is invented by crazy intellectuals in a café in Prague" (Komárek, as cited in Ram, 2015, p. 474). 
In contrast, the school principals and educators in our case study intentionally reached out to international organizations and their regional county to support inclusive efforts and better educational outcomes for Roma students. Among other achievements, they established the Roma Family Center, afterschool programs, free preschool, free bus transportation for the students, and supportive workshops for their parents.

While teachers' practices that include building a community of learners and small group collaboration are not a novelty, this educational approach implemented in place of lecturing was a new approach a decade ago. Also, while individual teachers occasionally visited Roma students' homes in the past, establishing the relationships with Roma communities and the faculty of all case schools was a new practice. Educators started to view their working hours as flexible and spent numerous hours volunteering in parental workshops. Such activities are some of the factors that have contributed to building relationships with Roma parents. Employing Roma assistants in K-8 schools also contributed to developing trust and better communication between the schools and the Roma parents.

In addition to educators' efforts, international funding applied to legalizing the settlements of Roma citizens seems crucial in diminishing the social exclusion of Roma communities. While still situated at the periphery of cities and towns as many other Roma communities across Croatia and other states, the three communities we visited seem to be on their way to being integrated geographically and socially, as well as educationally.

\section{References}

Baxter, P., \& Jack, S. (2008). Qualitative case study methodology: Study design and implementation for novice researchers. The Qualitative Report 13(4), 554-559.

Brüggemann, C. (2012). Roma education in comparative perspective. Analysis of UNDP/World Bank/EC Regional Roma Survey 2011. Roma Inclusion Working Papers. Bratislava, Slovakia: United Nations Development Programme.

Croatian Parliament. (2010). Amendments to the Constitution of the Republic of Croatia. Zagreb, Croatia: Narodne novine 76/2010. Retrieved from http://www.sabor.hr/Default.aspx?art=1839

Curcic, S., Miskovic, M., Plaut, S., \& Ceobanu, C. (2014). Inclusion, integration or perpetual exclusion? A critical examination of the Decade of Roma Inclusion, 2005-2015. European Educational Research Journal, 13 (3), 257267. doi: dx.doi.org/10.2304/eerj.2014.13.3.257 
European Commission. (2016.). European neighbourhood policy and enlargement negotiations. Retrieved from https://ec.europa.eu/neighbourhoodenlargement

European Commission. (2007). Instrument for pre-accession assistance (IPA). Retrieved from http://ec.europa.eu/regional_policy/hr/funding/ipa/

European Court of Human Rights (ECHR). (2010). Oršuš and Others v. Croatia (application no. 15766/03). Retrieved from http://hudoc.echr.coe.int/ eng?i=003-3069606-3394560

Fonseca, I. (1995). Bury me standing: The Gypsies and their journey. New York, NY: Random House.

Kárpáti, A., Molnár, E. D., \& Munkácsy, K. (2014). Pedagogising knowledge in multigrade Roma schools: Potentials and tensions of innovation. European Educational Research Journal 13(3), 325-337. doi: dx.doi.org/10.2304/ eerj.2014.13.3.325

Merriam, S. B. (1988). Case study research in education: A qualitative approach. San Francisco, CA: Jossey-Bass.

Messing, V. (2008). Good practices addressing school integration of Roma/Gypsy children in Hungary. Intercultural Education, 19(5), 461- 473. doi: 10.1080/ 14675980802531721

Miles, M. B., \& Huberman, A. M. (1994). Qualitative data analysis: An expanded sourcebook (2nd ed.). Thousand Oaks, CA: Sage.

Miskovic, M. (Ed.). (2013). Roma education in Europe: Practices, policies, and politics. London, United Kingdom: Routledge.

National Centre for External Evaluation of Education (NCEEE). (2010). More accessible and higher quality education of Roma in the Republic of Croatia. CR005. Retrieved from http://dokumenti.ncvvo.hr/Kvaliteta_obrazovanja/ Romi/analiza_rezultata.pdf

Open Academy Step by Step. (2015). Uciteljica (Teacher). Retrieved from https://vimeo.com/146106973

Padilla-Carmona, T., \& Soria-Vílchez, A., A. (2015). Supporting Roma students to access higher education: Good practice for widening the participation of Roma in Spanish higher dducation. Report as part of the Higher Education Internationalisation and Mobility: Inclusion, Equalities and Innovation Project. Marie Sklodowska-Curie Actions, Research and Innovation Staff Exchange, Horizon 2020. Grant agreement No. 643739. doi: 10.13140/ RG.2.1.3217.9924

Ram, M. H. (2015). International policy and Roma education in Europe: Essential inputs or centralized distractions? Alberta Journal of Educational Research, 61(4), 465-483.

Rostas, I., \& Kostka, J. (2014). Structural dimensions of Roma school desegregation policies in Central and Eastern Europe. European 
Educational Research Journal, 13(3), 268-281.

Sobotka, E., \& Vermeersch, P. (2012). Governing human rights and Roma inclusion: Can the EU be a catalyst for local social change? Human Rights Quarterly, 34(3), 800-822. doi: 10.1353/hrq.2012.0050

Stake, R. E. (1995). The art of case study research. Thousand Oaks, CA: SAGE.

Strauss, A., \& Corbin, J. (1998). Open coding. In A. Strauss \& J. Corbin (Eds.), Basics of qualitative research: Techniques and procedures for developing grounded theory (pp. 101-121). Thousand Oaks, CA: Sage.

Šikić-Mićanović, L., Ivatts, A. R., Vojak, D., \& Geiger-Zeman, M. (2015). Roma early childhood inclusion+: Croatia report. London, United Kingdom: Open Society Foundations.

Thomas, G. (2011). A typology for the case study in social science following a review of definition, discourse, and structure. Qualitative Inquiry, 17(6), 511-521.

United Nations, Department of Economic and Social Affairs, Population Division(2017). World population prospects: The 2017 revision, key findings and advance tables. Working Paper No. ESA/P/WP/24. New York, NY: United Nations. Retrieved from https://esa.un.org/ unpd/wpp/publications/ Files/WPP2017_KeyFindings.pdf

Urban, M. (2015). Sufficiently well informed and seriously concerned? European Union policy responses to marginalisation, structural racism, and institutionalised exclusion in early childhood. Alberta Journal of Educational Research, 61(4), 399-416.

White, J. (2012). Pitfalls and bias: Entry testing and the overrepresentation of Romani children in special education. Budapest, Hungary: Roma Education Fund.

World Bank (2010). Economic cost of Roma exclusion. The World Bank: Europe And Central Asia: Human Development Department. Retrieved from http://siteresources.worldbank.org/EXTROMA/Resources/Economic_Cost s_Roma_Exclusion_Note_Final.pdf

Yazan, B. (2015). Three approaches to case study methods in education: Yin, Merriam, and Stake. The Qualitative Report 20(2), 134-152.

Yin, R. K. (2003). Case study research: Design and methods (3rd ed.). Thousand Oaks, CA: Sage.

\section{Author Contact}

Svjetlana Curcic: scurcic@olemiss.edu

University of Mississippi, 1918 Briar Ridge Rd., Tupelo, MS 38804, USA 
Goran Lapat: goran.lapat@ufzg.hr

University of Zagreb, Faculty of Education - Department of Čakovec Ul. dr. Ante Starčevića 55, 40000, Čakovec, Croatia

Branko Susec: branko.susec@medjimurska-zupanija.hr Department for Education, Culture and Sport, Medjimurje County, Ruđera Boškovića 2, 40000 Čakovec,Croatia

Benjamin Ignac: benjamin.ignac@errc.org

European Roma Rights Center, Wesselényi utca 16, H-1077 Budapest, Hungary 